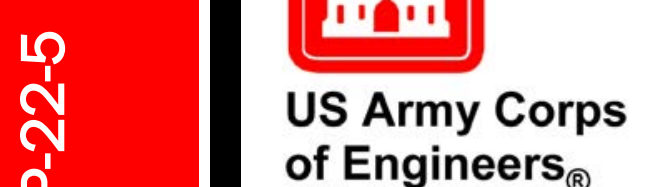

of Engineers ${ }_{\circledast}$

Engineer Research and

Development Center

\title{
A Comparison of Handheld Field Chemical Sensors for Soil Characterization with a Focus on LIBS
}

Jay Clausen, Richard Hark, Russ Harmon, John Plumer,

February 2022

Sam Beal and Meghan Bishop 
The U.S. Army Engineer Research and Development Center (ERDC) solves the nation's toughest engineering and environmental challenges. ERDC develops innovative solutions in civil and military engineering, geospatial sciences, water resources, and environmental sciences for the Army, the Department of Defense, civilian agencies, and our nation's public good. Find out more at www.erdc.usace.army.mil.

To search for other technical reports published by ERDC, visit the ERDC online library at https://erdclibrary.on.worldcat.org/discovery. 


\section{A Comparison of Handheld Field Chemical Sensors for Soil Characterization with a Focus on LIBS}

Jay Clausen and Sam Beal

Cold Regions Research and Engineering Laboratory

U.S. Army Engineer Research and Development Center

72 Lyme Road, Hanover, NH 03775

Richard Hark

Yale University

New Haven, CT 06520

Russ Harmon

North Carolina State University

Raleigh, NC 27695

John Plummer

JR Plummer \& Associates, LLC

P.O. Box 566, Belmont, NH 03220

Meghan Bishop

U.S. Department of Energy

Oak Ridge Institute for Science and Education

Oak Ridge, TN 37830

Final report

Approved for public release; distribution is unlimited.

Prepared for U.S. Army Corps of Engineers

Washington, DC 201314

Under Project T15, Program Element 633734, Task 2 


\section{Preface}

This study was conducted for the U.S. Army Corps of Engineers with funding under Army Direct Project T15, Program Element 633734, Task 2.

The work was performed by the Biogeochemical Sciences Branch (Mr. Nathan Lamie, Chief) of the of the Research and Engineering Division (Dr. George Calfas, Chief), U.S. Army Engineer Research and Development Center, Cold Regions Research Engineering Laboratory (ERDC-CRREL); North Carolina State University; Yale University; J R Plummer \& Associates, and the Oak Ridge Institute for Science and Education. At the time of publication of this paper, the deputy director for ERDC-CRREL was Mr. Bryan E. Baker and the director was Dr. J oseph Corriveau.

This material was originally presented at the SCIX 21 Conference on 17 September 2021.

The commander of ERDC was COL Teresa A. Schlosser and the director was Dr. David W. Pittman.

DISCLAIMER: The contents of this report are not to be used for advertising, publication, or promotional purposes. Citation of trade names does not constitute an official endorsement or approval of the use of such commercial products. All product names and trademarks cited are the property of their respective owners. The findings of this report are not to be construed as an official Department of the Army position unless so designated by other authorized documents. 


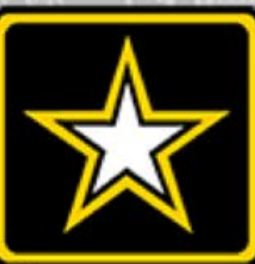

U.S.ARMY

A COMPARISON OF HANDHELD FIELD CHEMICAL SENSORS FOR SOIL CHARACTERIZATION WITH A FOCUS ON LIBS

Prepared by Jay Clausen

USACE, ERDC-CRREL, Biogeochemical Sciences Branch

SCIX2021

17 September 2021

DISTRIBUTION STATEMENT HERE

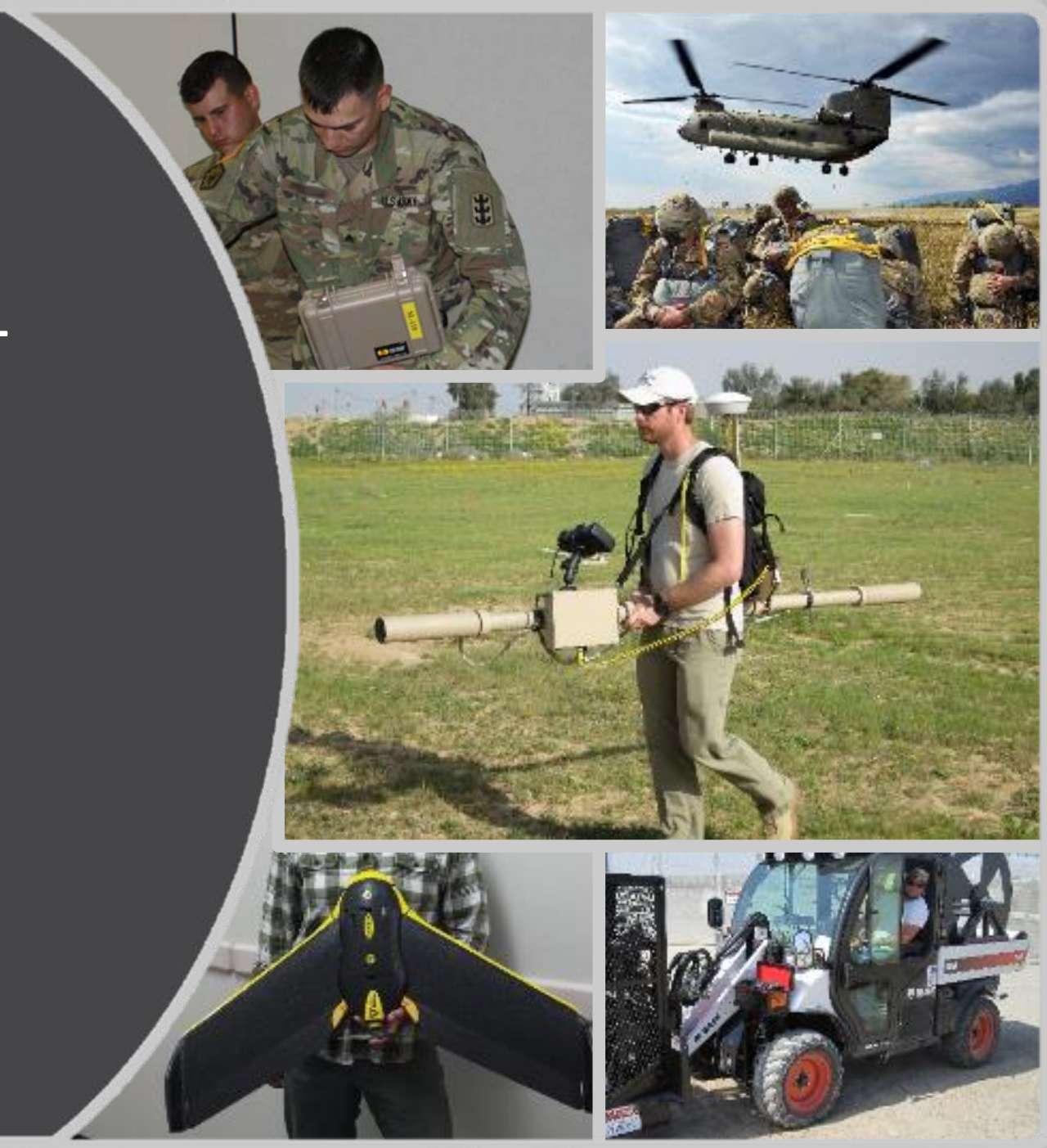
ERDC 


\section{Acknowledgements}

- Richard Hark (Yale)

- Russ Harmon (North Carolina State University)

- John Plumer ( JRPlumer \& Associates)

- Sam Beal (ERDC-CRREL)

- Meghan Bishop (ORISE) 


\section{Objective}

- Sensors capable of characterizing/monitoring the environment

o Proximal distances

o Battlefield or military training ranges

- Environmental awareness

- Environmental characterization

- Exposure

- Evaluate hand-held LIBS for characterization of metals ( $\mathrm{Sb}, \mathrm{Cu}, \mathrm{Pb}, \mathrm{W}$, and Zn) in soil and compare with XRF and ICP-AES

o Soils from military training ranges and other sites

o Standard reference materials

o Certified reference materials

- Ascertain precision, accuracy, sensitivity, and reproducibility of hand-held LIBS technology

Go (Green), Slow-Go (Yellow), No-Go (Red) suitability map for a given sensor modality in a given region of the world at relevant spatial resolutions 


\section{What Does the Soldier Want}

\section{FOB}

Environmental Characterization

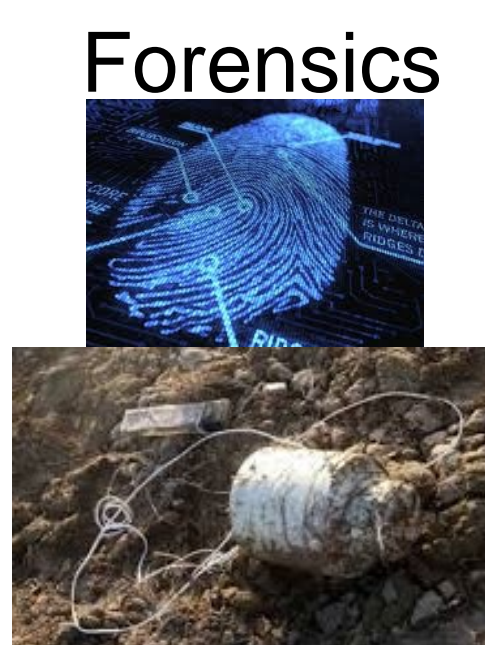

Countermine Detection

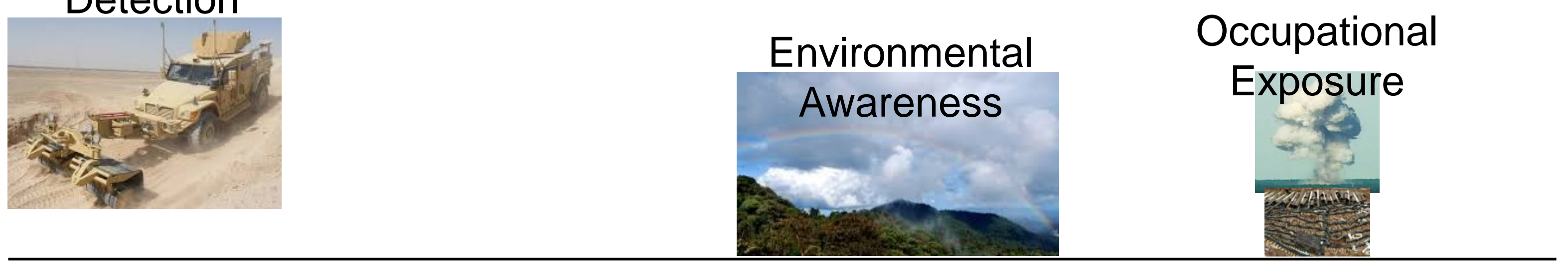




\section{What Does the Soldier Want}

$\mathrm{FOB}$

Environmental Characterization



Countermine Detection
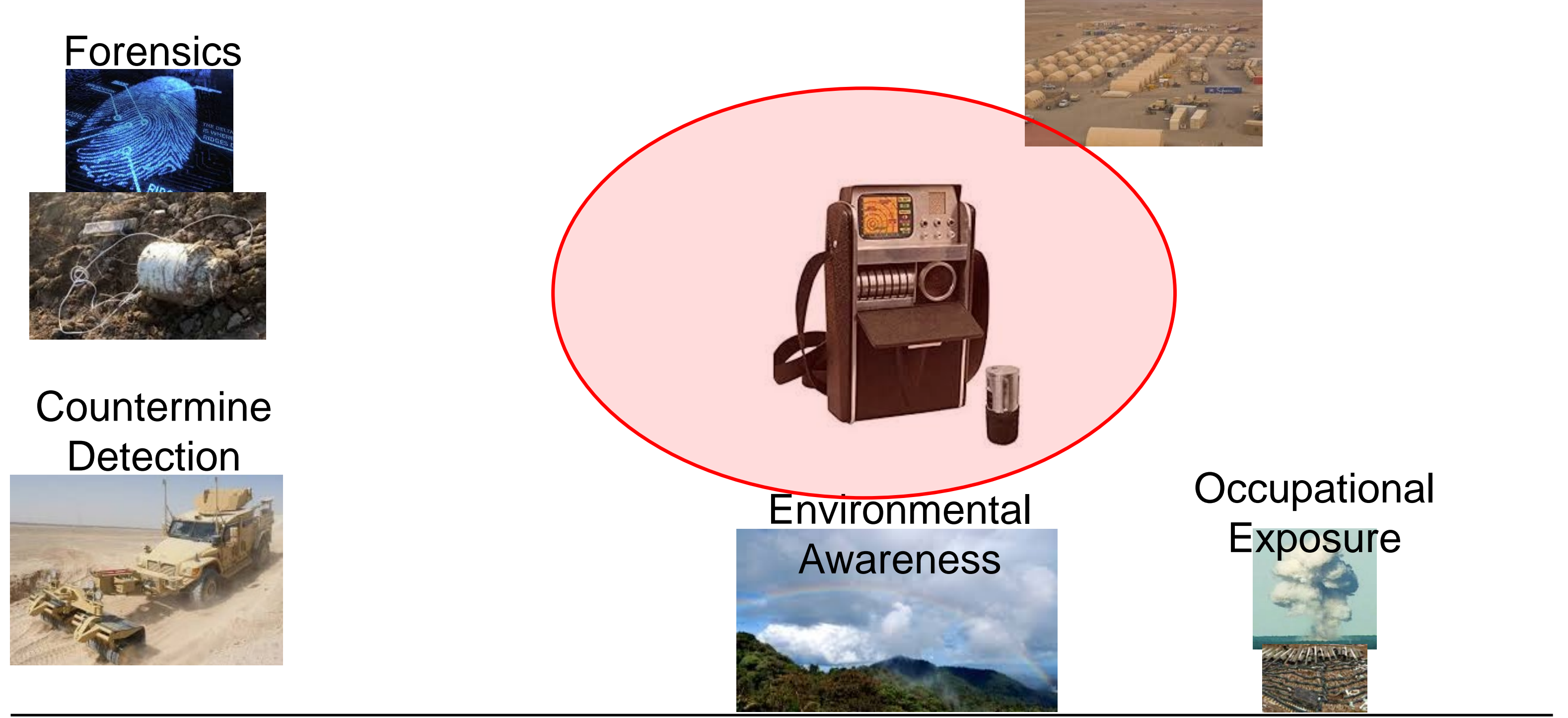


\section{What Does the Soldier Want}

Forensics

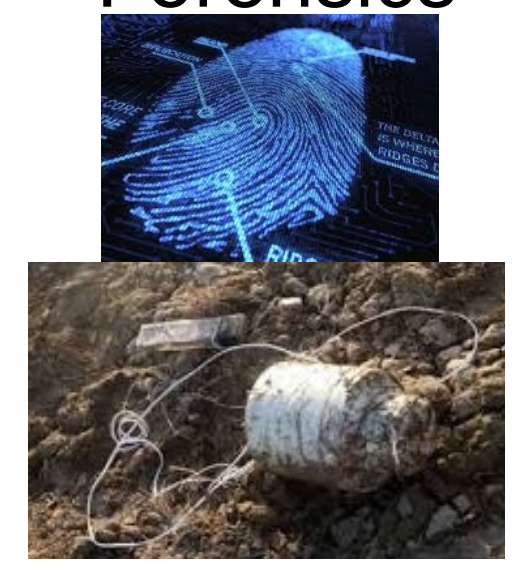

Countermine Detection
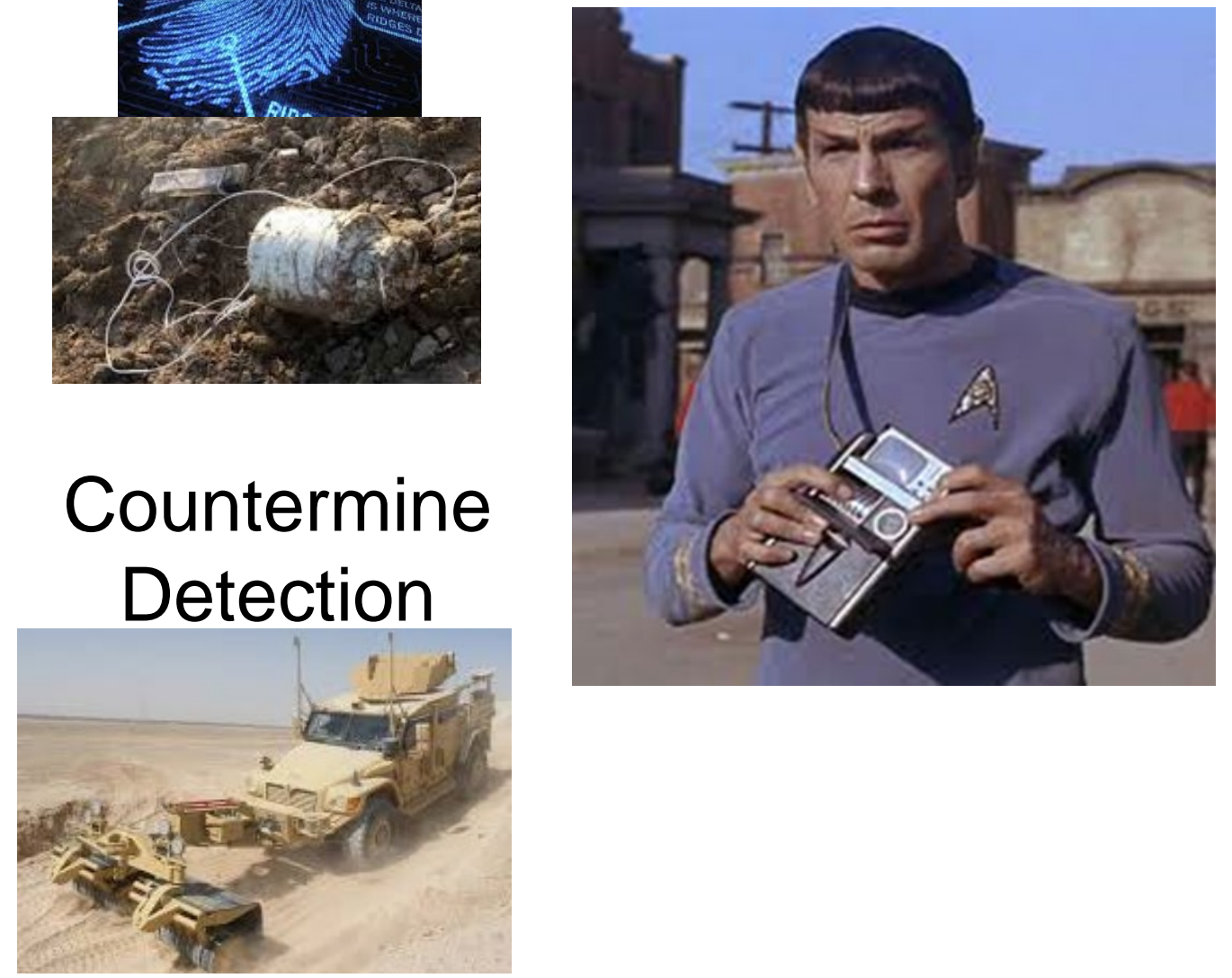

Tricorder

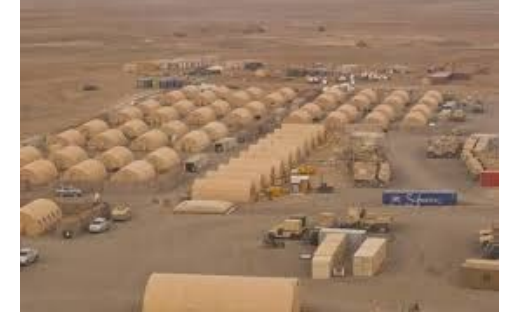

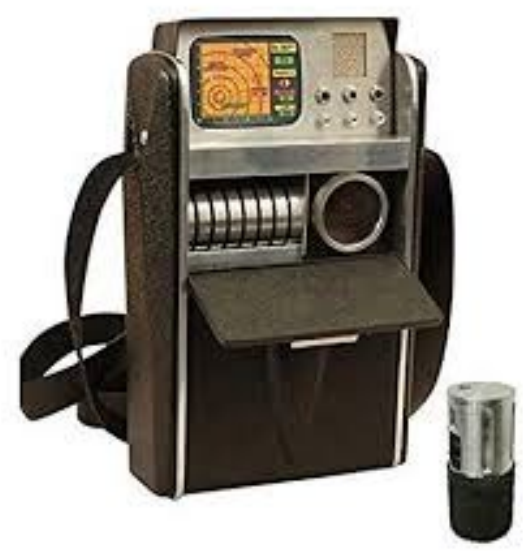

Environmental Awareness
Occupational Exposure 


\section{What Does the Soldier Want}

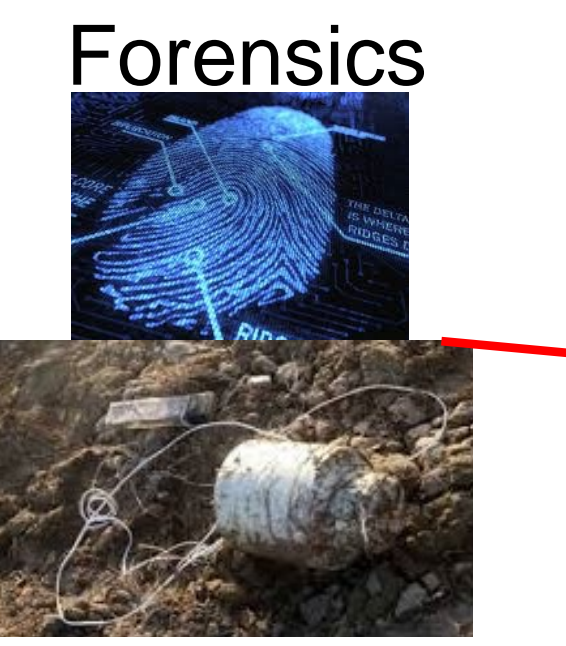

Countermine Detection

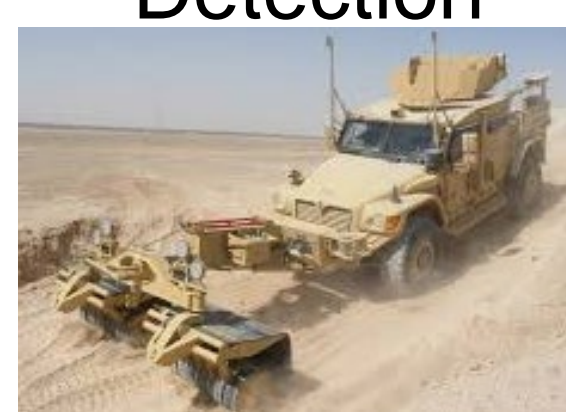

Environmental Awareness



\section{Environmental Characterization}

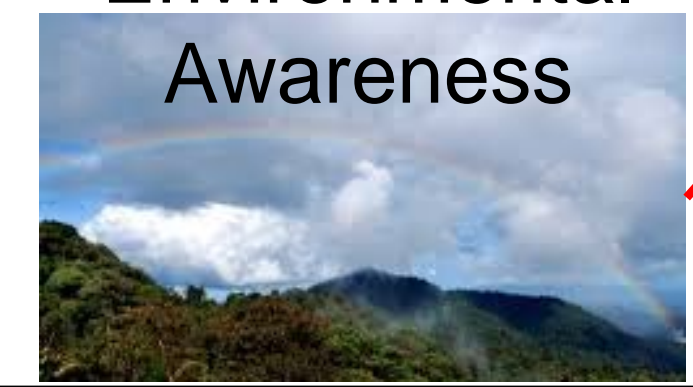

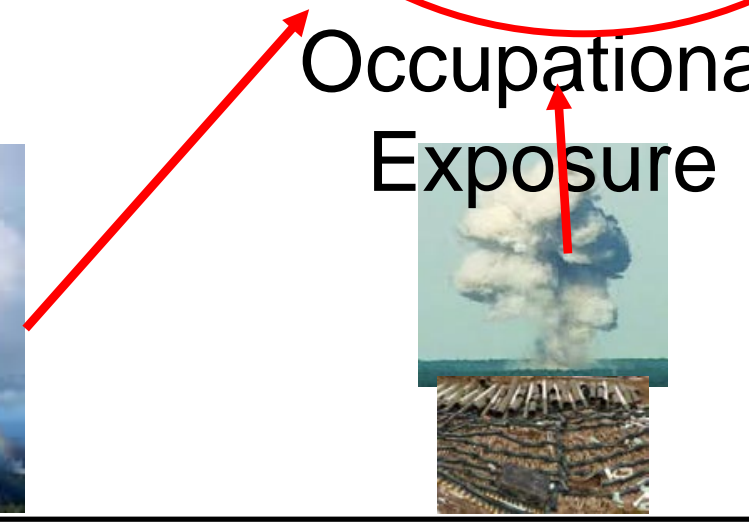




\section{Conventional Analytical Approach}

- Analysis in fixed-based laboratory

- ICPIAES-MS, HPLC, LC/MS, GC/MS

- Metals, energetics, VOCs, SVOCs, pesticides, herbicides, dioxins, PCBs, perchlorate, cyanide, nutrients, etc.
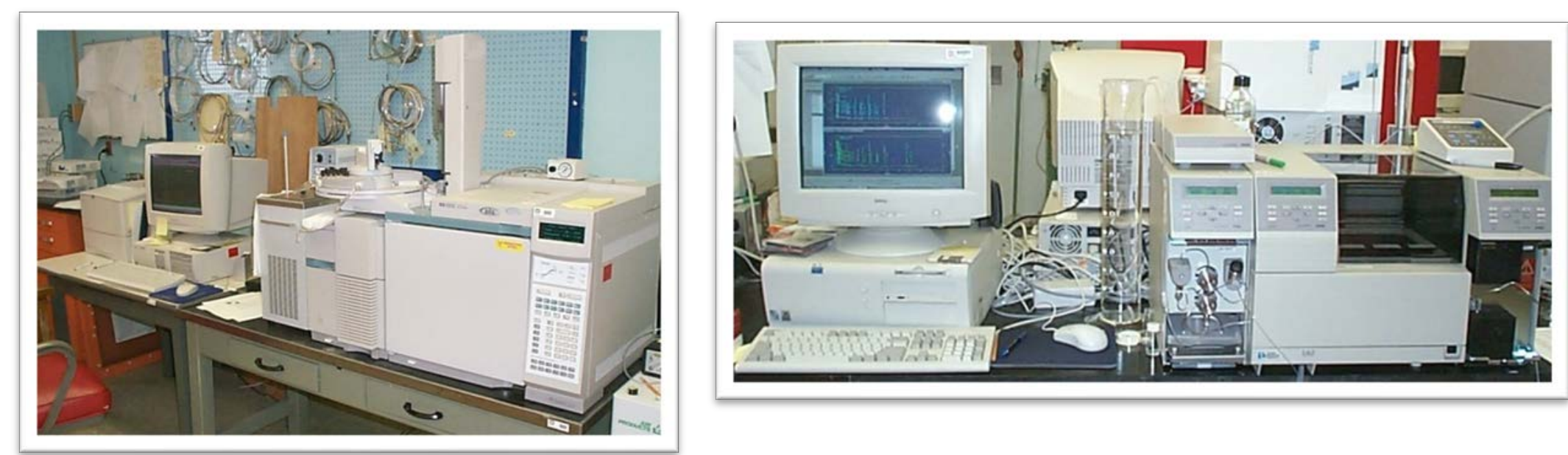

- In-field analysis with hand-held XRF

- Metals
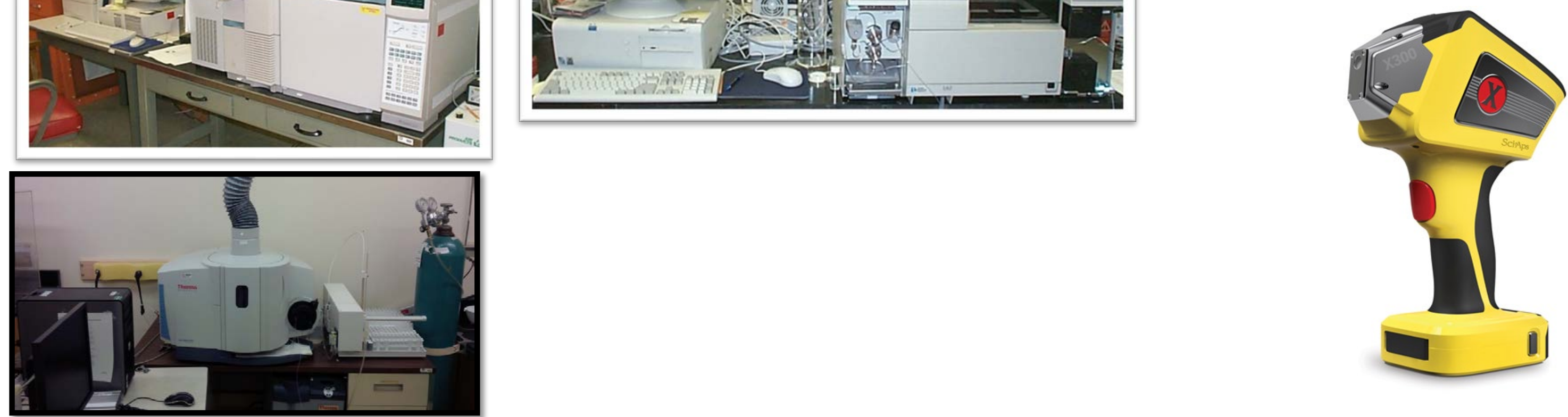


\section{Next Generation Technology: Laser Induced Breakdown Spectroscopy (LIBS)}
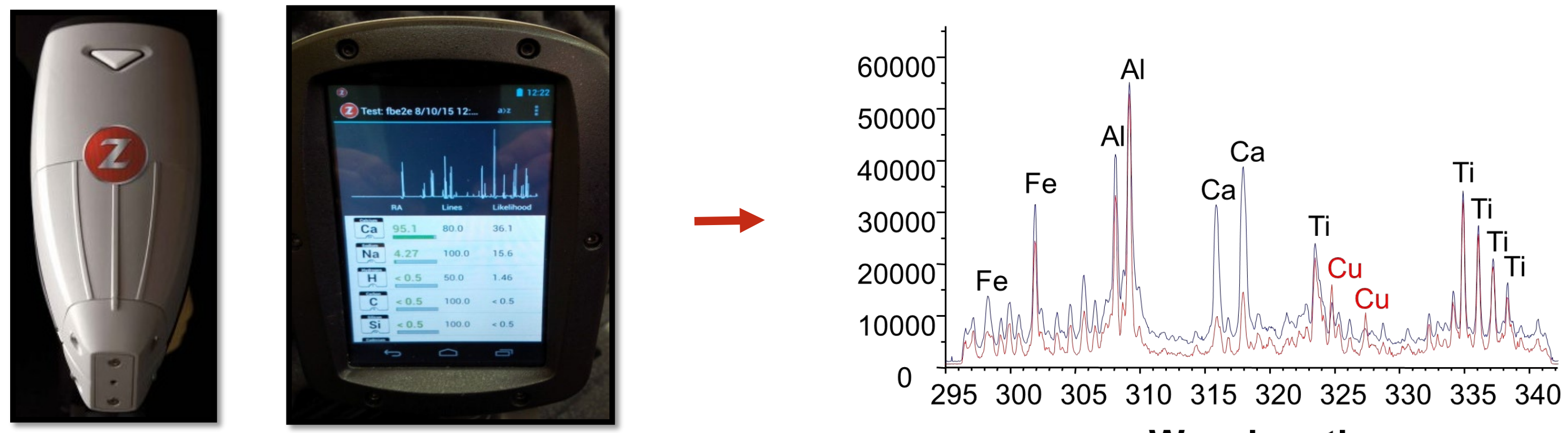

Wavelength, $\mathrm{nm}$

a) Laser ablation of material of interest

b) Development of plasma field

c) Collection of resulting spectra with optical spectrograph

d) Software based analysis of spectral data

e) Results 


\section{Methods - Sample Processing}
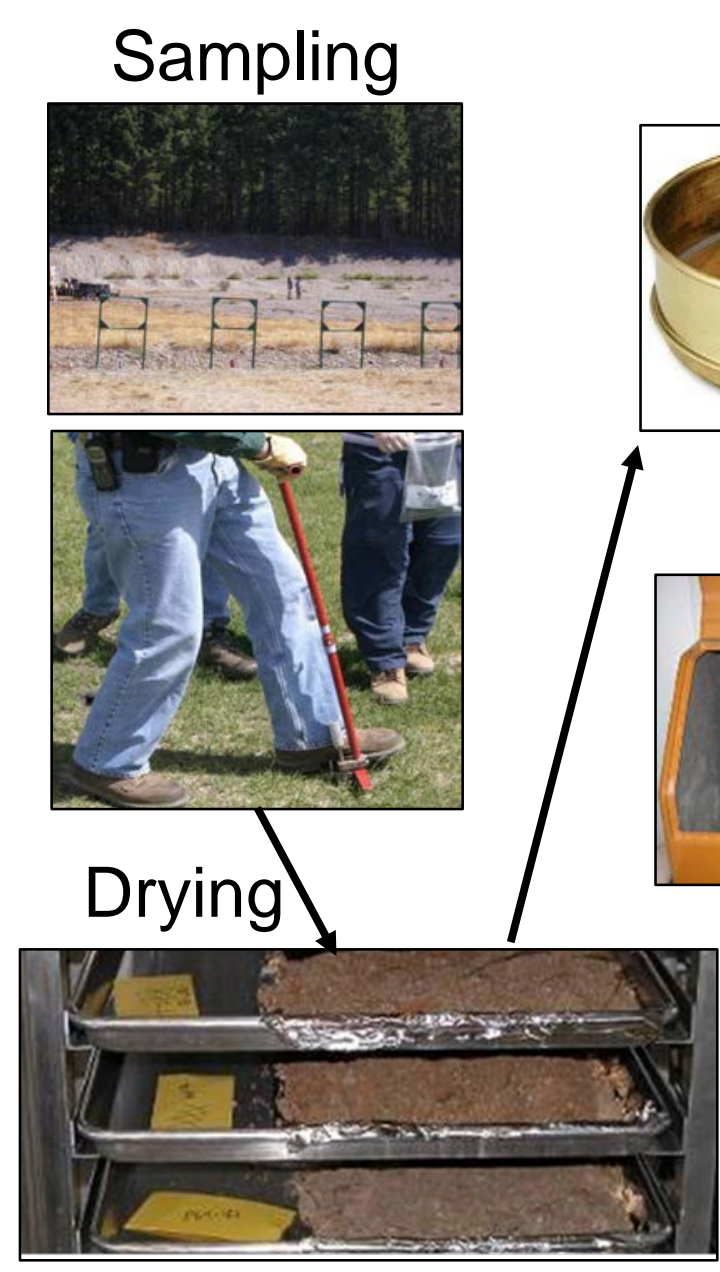

Sieving
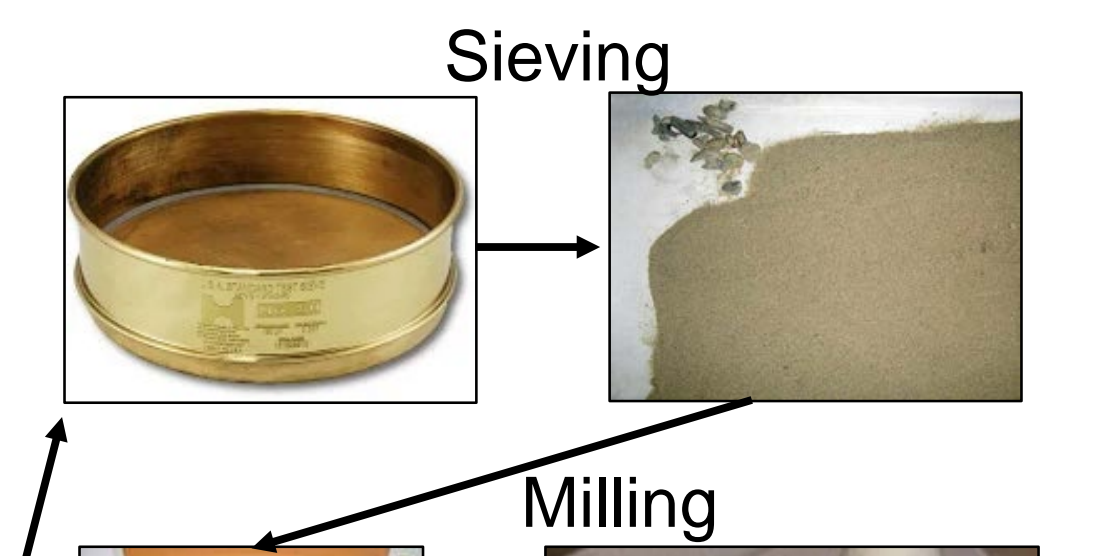

\section{Subsampling}

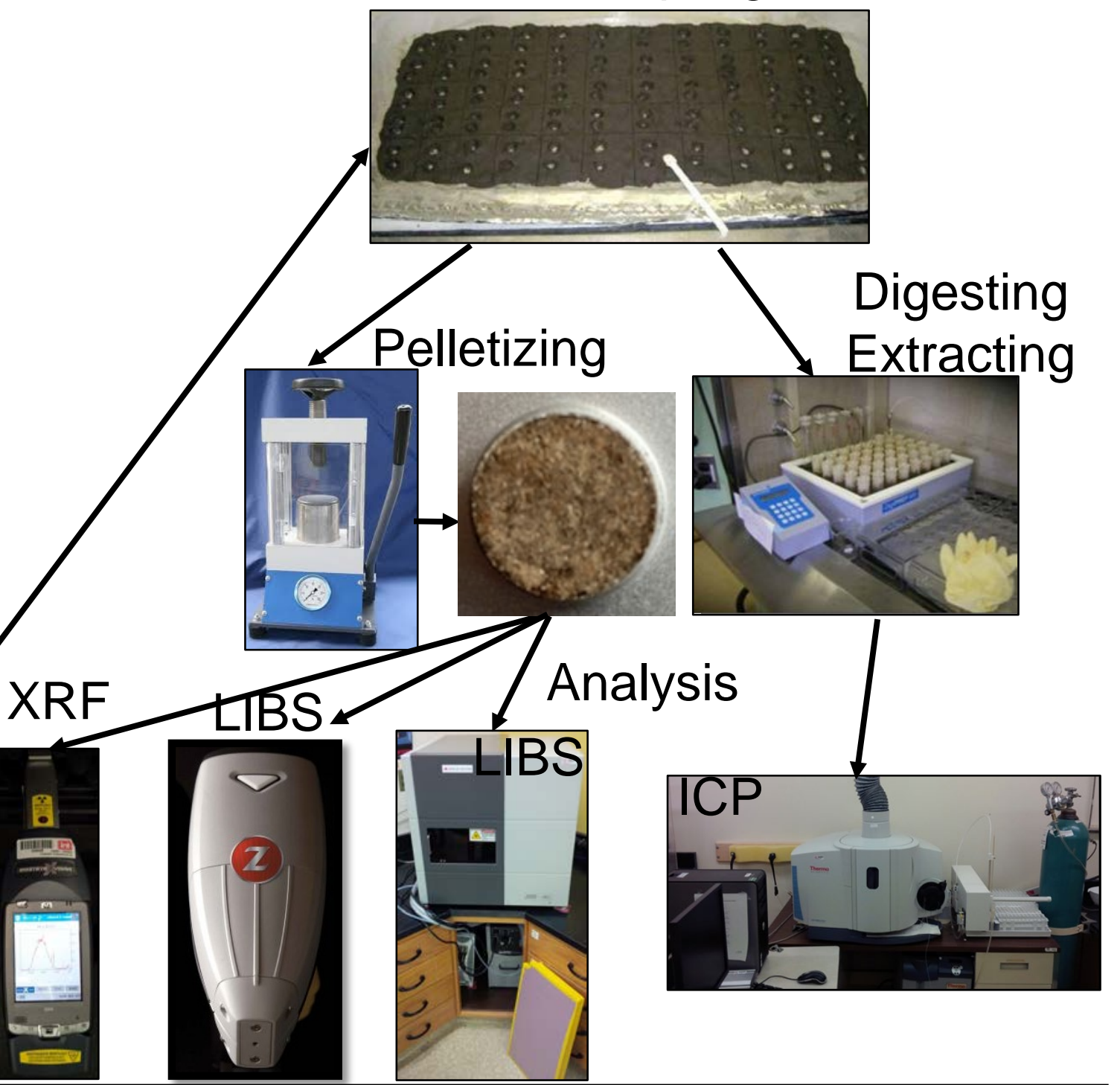




\section{XRF and LIBS Measured Values vs Certified Values}
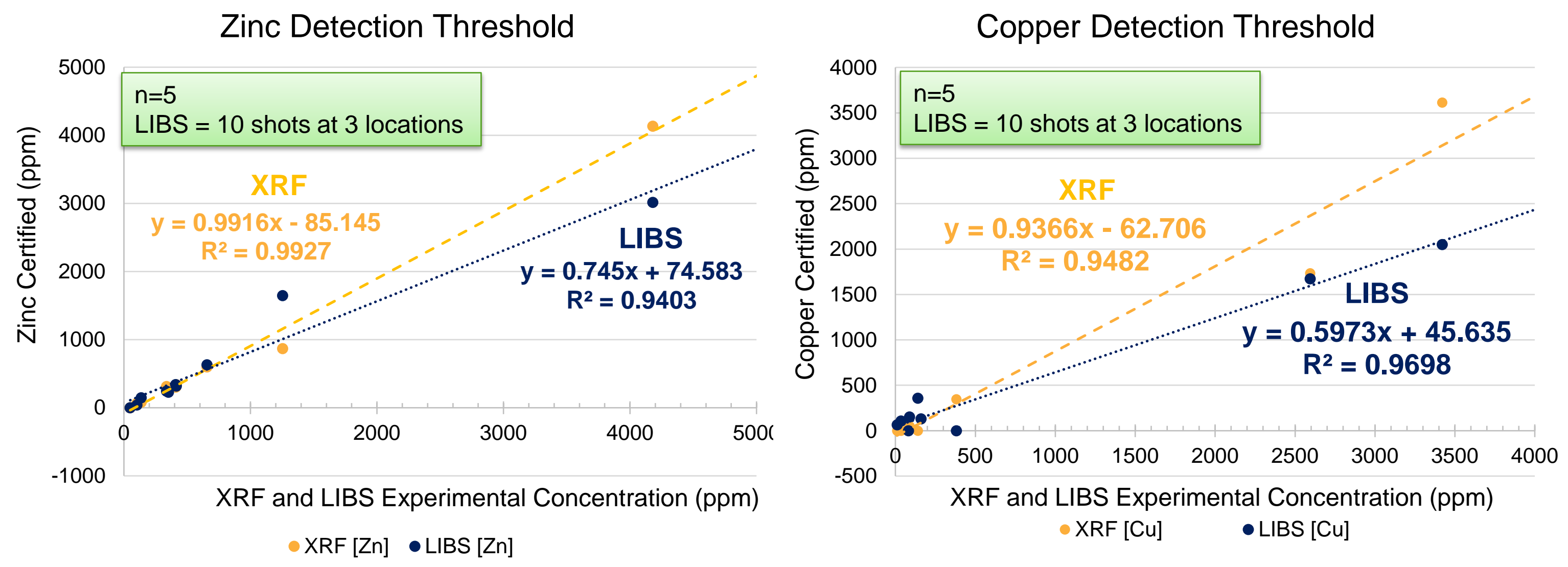


\section{LIBS versus XRF}






\section{Instrument versus Sample Variability}

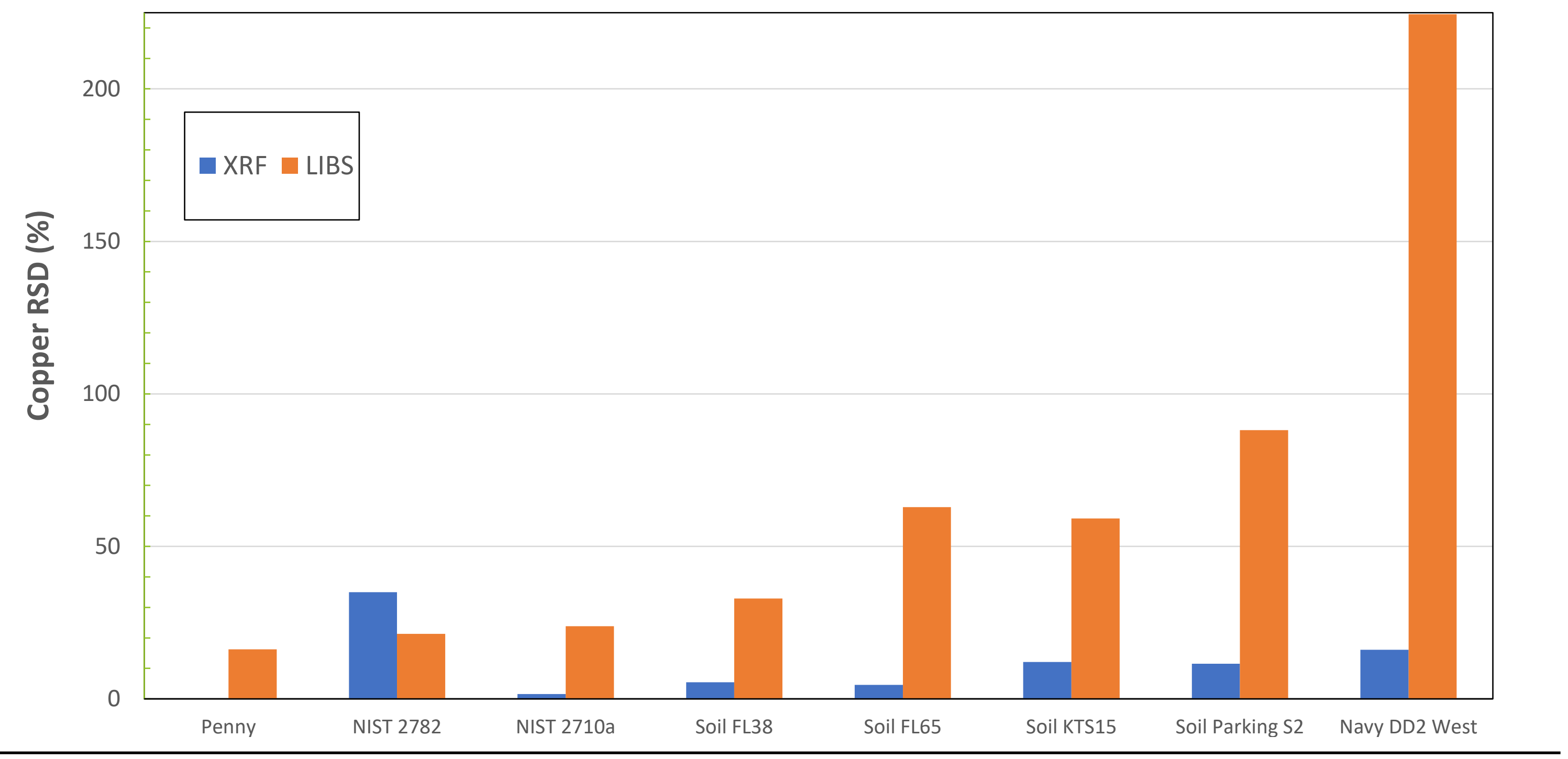




\section{Particle Size Issue}
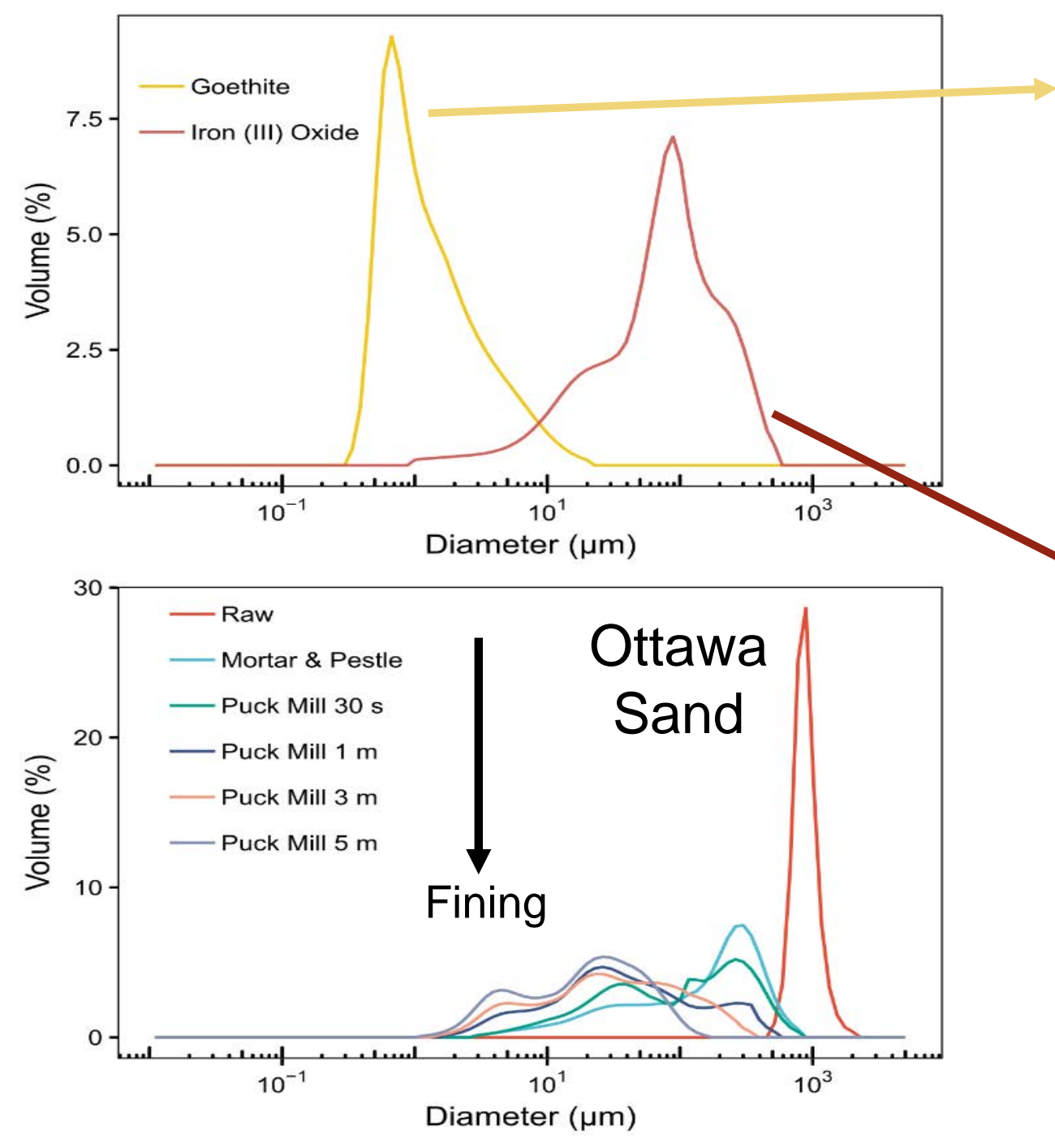

Goethite


US Army Corps of Engineers • Engineer Research and Development Center 


\section{LIBS Intensity as Function of Particle Size}

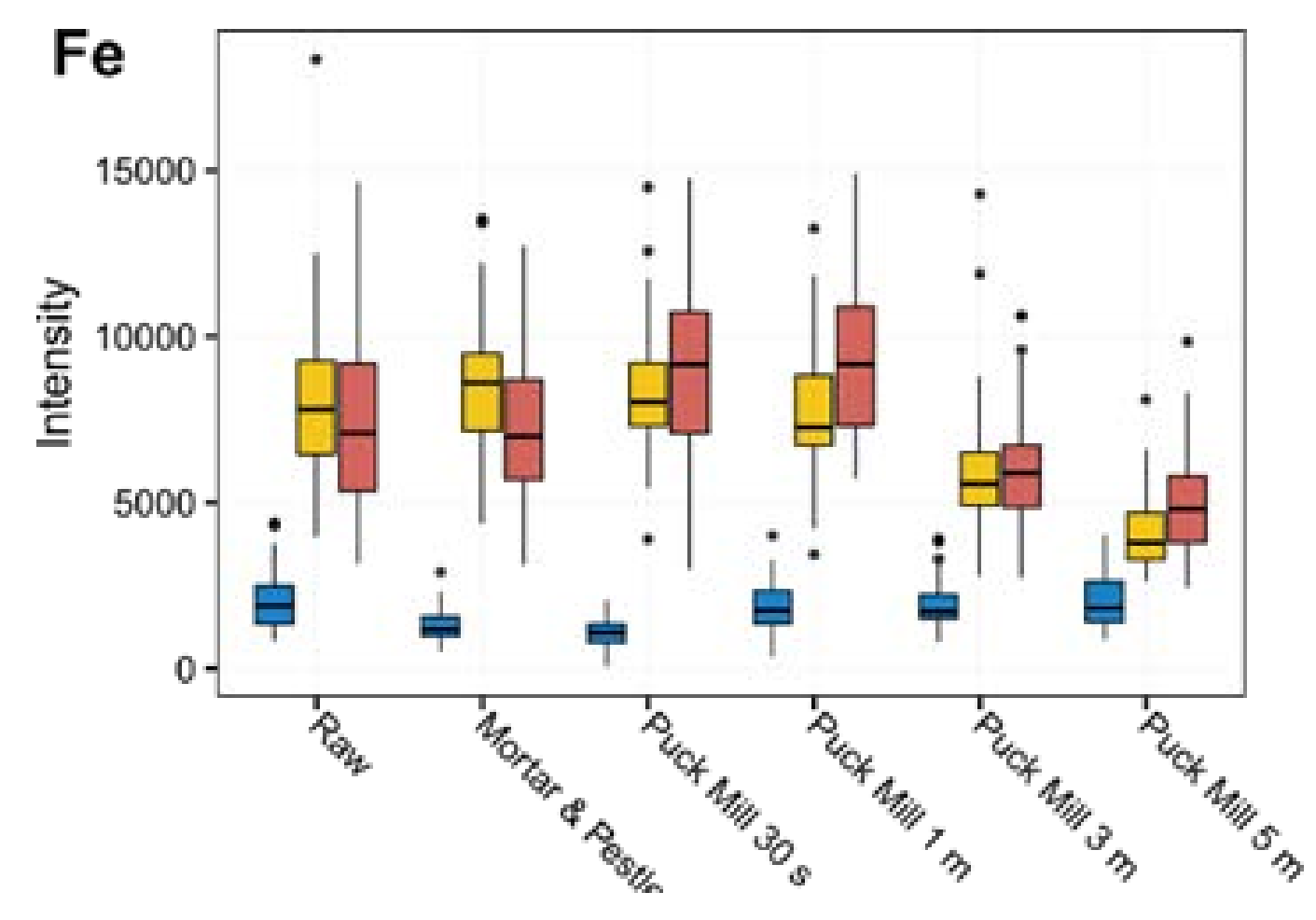

Course

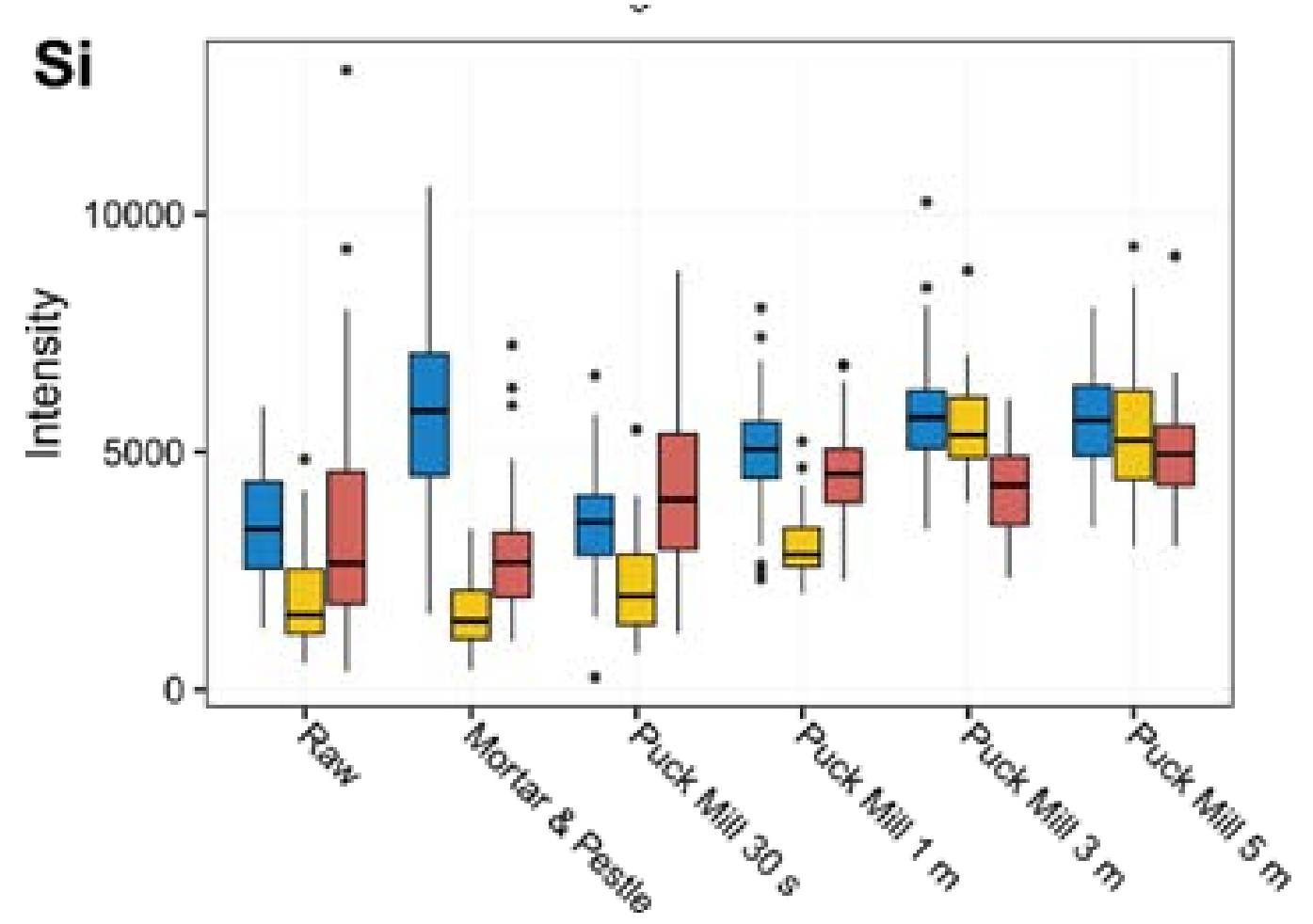

$\bigoplus B$ Blank

Goethite

Giron (III) Oxide 


\section{Conclusions}

- Copper and zinc LIBS measurement in agreement with known value of analytical NIST standards

- Lead data, not shown, in poor agreement

- LIBS appears to underpredict copper and zinc concentrations as compared to XRF and known quantity

- Poor agreement between XRF and LIBS measurements of same sample for copper and zinc

- Variability as measured by percent Relative Standard Deviation appears to be due to sample heterogeneity

- Another issue contributing to LIBS variability is particle size

- Particle size differences are analyte specific, and outcomes can

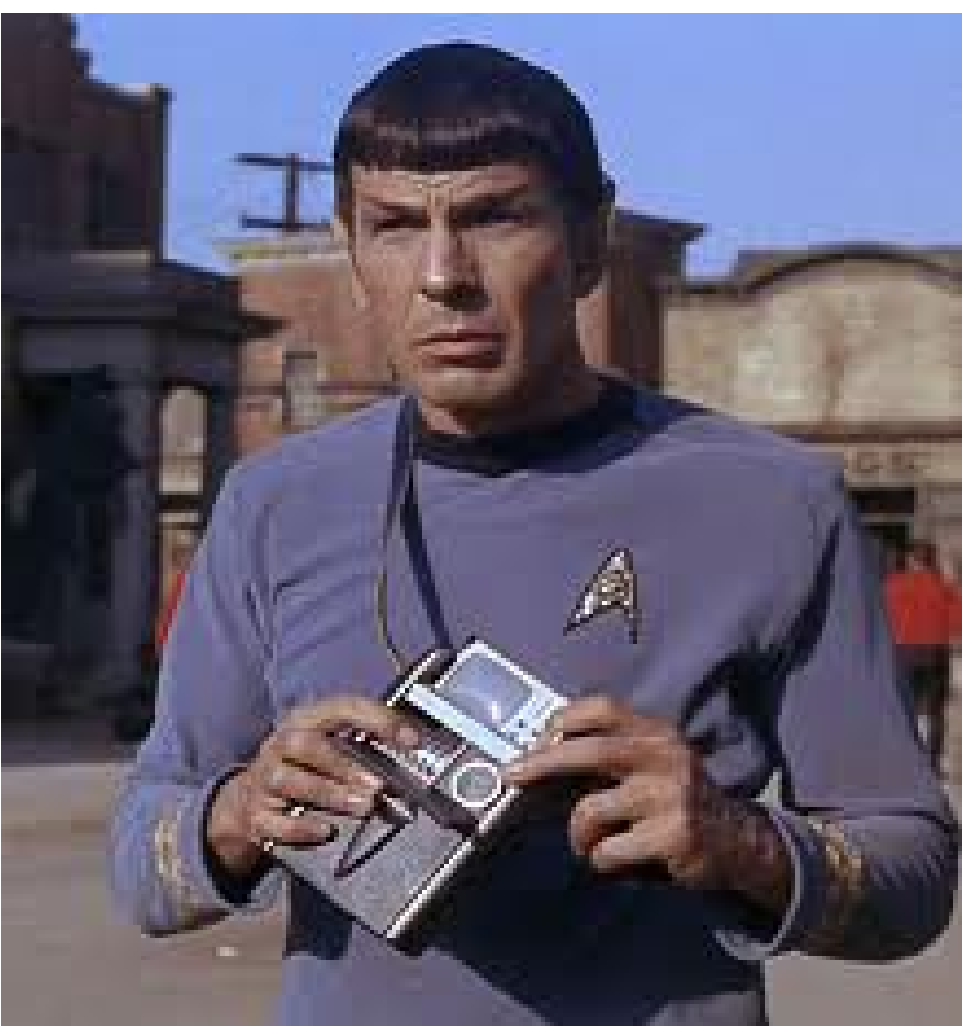
be diametrically opposed 


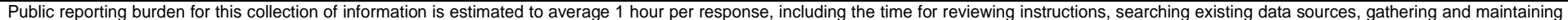

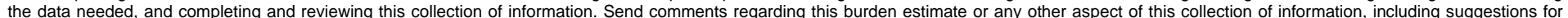

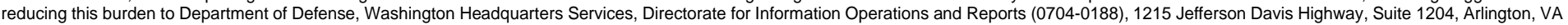

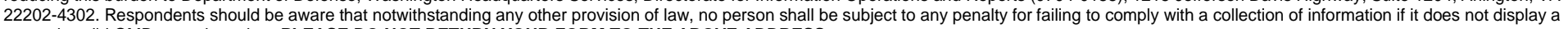
currently valid OMB control number. PLEASE DO NOT RETURN YOUR FORM TO THE ABOVE ADDRESS.
1. REPORT DATE
February 2022
2. REPORT TYPE
Final

\section{TITLE AND SUBTITLE}

A Comparison of Handheld Field Chemical Sensors for Soil Characterization with a

Focus on LIBS

\section{DATES COVERED (From - To)}

\section{5a. CONTRACT NUMBER}

5b. GRANT NUMBER

5c. PROGRAM ELEMENT NUMBER

633734

\section{AUTHOR(S)}

Jay Clausen, Richard Hark, Russ Harmon, John Plumer, Sam Beal, and Meghan Bishop

5d. PROJECT NUMBER

T15

5e. TASK NUMBER

2

5f. WORK UNIT NUMBER

7. PERFORMING ORGANIZATION NAME(S) AND ADDRESS(ES)

See next page.

8. PERFORMING ORGANIZATION REPORT
NUMBER

ERDC/CRREL MP-22-5

9. SPONSORING / MONITORING AGENCY NAME(S) AND ADDRESS(ES)

U.S. Army Corps of Engineers

Washington, DC 20314

10. SPONSOR/MONITOR'S ACRONYM(S)

USACE

11. SPONSOR/MONITOR'S REPORT NUMBER(S)

\section{DISTRIBUTION / AVAILABILITY STATEMENT}

Approved for public release; distribution is unlimited.

\section{SUPPLEMENTARY NOTES}

This material was originally presented at the SCIX Conference on 17 September 2021.

Funding was by Army Direct Project T15.

\section{ABSTRACT}

Commercially available handheld chemical analyzers for forensic applications have been available for over a decade. Portable systems from multiple vendors can perform X-ray fluorescence (XRF) spectroscopy, Raman spectroscopy, Fourier transform infrared (FTIR) spectroscopy, and recently laser-induced breakdown spectroscopy (LIBS). Together, we have been exploring the development and potential applications of a multisensor system consisting of XRF, Raman, and LIBS for environmental characterization with a focus on soils from military ranges. Handheld sensors offer the potential to substantially increase sample throughput through the elimination of transport of samples back to the laboratory and labor-intensive sample preparation procedures. Further, these technologies have the capability for extremely rapid analysis, on the order of tens of seconds or less. We have compared and evaluated results from the analysis of several hundred soil samples using conventional laboratory bench top inductively coupled plasma atomic emission spectroscopy (ICP-AES) for metals evaluation and high-performance liquid chromatography (HPLC) and Raman spectroscopy for detection and characterization of energetic materials against handheld XRF, LIBS, and Raman analyzers. The soil samples contained antimony, copper, lead, tungsten, and zinc as well as energetic compounds such as 2,4,6-trinitrotoluene (TNT), hexahydro-1,3,5-triazine (RDX), nitroglycerine (NG), and dinitrotoluene isomers (DNT). Precision, accuracy, and sensitivity of the handheld field sensor technologies were compared against conventional laboratory instrumentation to determine their suitability for field characterization leading to decisional outcomes.

\section{SUBJECT TERMS}

Scientific apparatus and instruments; Chemistry, Analytic; Soils-Testing; Raman spectroscopy; X-ray spectroscopy; Laser-induced breakdown spectroscopy

\section{SECURITY CLASSIFICATION OF:}

\section{a. REPORT}

Unclassified

\begin{tabular}{|c|c|}
\hline $\begin{array}{c}\text { b. ABSTRACT } \\
\text { Unclassified }\end{array}$ & $\begin{array}{r}\text { c. THIS PAGE } \\
\text { Unclassified }\end{array}$ \\
\hline
\end{tabular}

\begin{tabular}{|c|c|}
$\begin{array}{c}\text { 17. LIMITATION } \\
\text { OF ABSTRACT }\end{array}$ & $\begin{array}{c}\text { 18. NUMBER } \\
\text { OF PAGES }\end{array}$ \\
UU & 22 \\
\hline
\end{tabular}

19a. NAME OF RESPONSIBLE PERSON

19b. TELEPHONE NUMBER (include area code) 
7. PERFORMING ORGANIZATION NAME(S) AND ADDRESS(ES)

Cold Regions Research and Engineering Laboratory U.S. Army Engineer Research and Development Center 72 Lyme Road, Hanover, NH 03775

Yale University

New Haven, CT 06520

North Carolina State University

Raleigh, NC 27695

JR Plummer \& Associates, LLC

P.O. Box 566, Belmont, NH 03220

Oak Ridge Institute for Science and Education

U.S. Department of Energy

Oak Ridge, TN 37830 